\section{Torsten Amundson och hans forskningsfond}

Göran Söderström

$\mathrm{U}$ nder sin vistelse vid Magnus Hirschfelds institut för sexualforskning i Berlin på 1930-talet fick den svenske sexualupplysaren och homosexuelle aktivistpionjären Eric Thorsell kännedom om en förmögen svensk läkare som fungerade som kontaktman för institutet, allmänpraktiserande läkaren Torsten Amundson (1878-1940). Hemkommen till Sverige skrev han till doktor Amundson och föreslog bildandet av en svensk motsvarighet till Wissenschaftlich-humanitäre Komitee, men fick ett avvisande svar:

Jag har alltid även för sanitetsrådet Hirschfeld framhăllit som min åsikt att i Sverige vore bäst om icke nägon propaganda bedrevs, dà svenskarna likna engelsmännen i hyckleri på detta område, och att jag hoppades, att en ändring av lagen liksom i Danmark och Norge lättare skulle komma till stảnd, om inte den stora allmänheten genom agitation drevs till att sannolikt pá alla sätt motarbeta en lycklig reform.

(Silverstolpe/Thorsell $1980 \mathrm{~s} 108$ )

Amundson uppgav också urskuldande att han förlorat alla sina pengar i samband med Kreugerkraschen, vilket var en sanning med stor modifikation.

Amundson tillhörde en förmögen familj från gården Stora Frösunda i Solna. Sedan han blivit färdig läkare vid 27 års ảlder studerade han vidare i Berlin, Wien och Paris 1905-1906 och kom sannolikt därvid i kontakt med Hirschfeld. Tillbaka i Stockholm flyttade han in i en ståtlig våning Strandvägen 1 tillsammans med sin 76 ảr gamla mormor och sin "assistent och gode vän" sjukgymnasten Eric Andersson (Ảhsberg) (1883-1936). Förhållandet tycks helt ha accepterats av familjen; i en tryckt släktkrönika berättas om detta originella familjeliv:

Pă lördagarna gick Torsten och hans vän och assistent Erik Andersson på Operakaféet tillsammans med [mormor] Selma för att höra god musik, dricka kaffe och äta bakelser. I sina memoarer berättar Selma att Torsten och hon ofta tillbringade hela söndagar på Stora Frösunda, men iblanc gjorde de làngturer med bảt eller tåg till Sandhamn, Nynäs, Södertälje med flera ställen. Hon berättar ocksá att "mina herrar äro nykterister så någon sprit kom aldrig ifrảga".

Är 1924 flyttade Amundson till det praktfullt bebyggda godset Engsholm i Ytterjärna nära Stockholm, men hade fortsatt nära och varm kontakt med sin familj. Av beskrivningen i "Svenska slott och herresäten" (Ny samling 1934 s 33-64 ) framgår det att de 33 rummen var fyllda av konst och antikviteter av hög klass. När Ảhsberg avled år 1936 anordnade Amundson en gemensam gravplats på Ytterjärna kyrkogård, utmärkt med en väldig bautasten med deras båda namn. I Amundsons testamente 1940 erbjuder han också sin dảvarande "privatsekreterare" att ligga i samma grav till vars ständiga skötsel han donerar en fond: sekreteraren erhåller också ett årligt livstidslegat därest jag icke uttryckligen förklarar, att ban brustit $i$ mitt förtroende, eller brutit förbindelsen med mig.

I samma testamente, upprättat med hjälp av den kände radikale advokaten Hugo Lindberg och godkänt av alla släktingar, skänker Amundson större delen av sin förmögenhet till en fond,

för bekostande av studier över homosexualiteten, dess uppkomst och förklaring, och upplysningsarbete för hävande av fördomar och oriktiga uppfattningar beträffande densamma samt mot homosexualitetens kriminalisering. Fondens medel skola $\mathrm{i}$ första hand användas för ovan nämnda upplysnings- och forskningsarbete i Sverige, Tyskland, England och Amerikas Förenta Stater.

Amundson önskade att fonden skulle förvaltas av Vetenskapsakademien "eller annan däremot svarande välkänd och vidsynt organisation". Det visade sig emellertid att akademien alls inte var vidsynt. Som villkor för att ta emot fonden krävde man att fondens ändamål skulle ändras, med den krystade motiveringen att efter strafflagskommitténs betänkande fortsatt upplysningsarbete var onödigt och att man nu visste att homosexualitet orsakades av hormonella rubbningar. Förloppet skildras i släktkrönikan:

Torsten hade uppenbarligen sina misstankar om att KVA inte ville befatta sig med forskning om homosexualiteten. Han hade nog alldeles rätt. Inte ens văr främsta akademi på medicinens område torde ha varit opåverkad av tidens uppfattning $i$ dessa frågor. Samtidigt var akademien nog mer än angelägen om att få ta hand om det aktningsvärda beloppet. [...]

Hur gjorde nu KVA med Torsten Amundsons önskemål? Exakt hur det gick till vet vi inte. Man löste det emellertid elegant. Akademien utfärdade "särskilda bestämmelser", som arvingarna accepterade. Omgivningens opinionstryck var vid denna tid självfallet vida större för en privatfamilj än vad det borde ha varit för en vidsynt akademi.

Forskningen om homosexualiteten fick följande formulering: "Vetenskap- 
lig forskning rörande hormoner eller hormonala rubbningar företrädesvishos människor och varmblodiga djur". (S 87)

Fram till 1992 utdelades ărligen stora summor ur fonden till ändamål som alla saknade varje samband med den homosexuella frågan. Ảr 1993 lyckades äntligen de då levande släktingarna med RFSLs hjälp övertala akademien att àtergå till den ursprungliga ändamålslydelsen. Första utdelningen efter de ändrade bestämmelserna ledde till protester från en rad akademiska forskare, eftersom de stödda projekten ansågs huvudsakligen avse starkt föråldrad former av orsaksforskning grundade på redan vederlagda teorier. 1995 års utdelning tillfredsställde däremot forskarsamhällets krav på vidsyn och objektivitet och innebar bland annat ekonomiskt stöd till återutgivningen av föreliggande vetenskapliga specialpublikation för homosexuell forskning, något som sannolikt skulle ha legat doktor Amundson varmt om hjärtat.

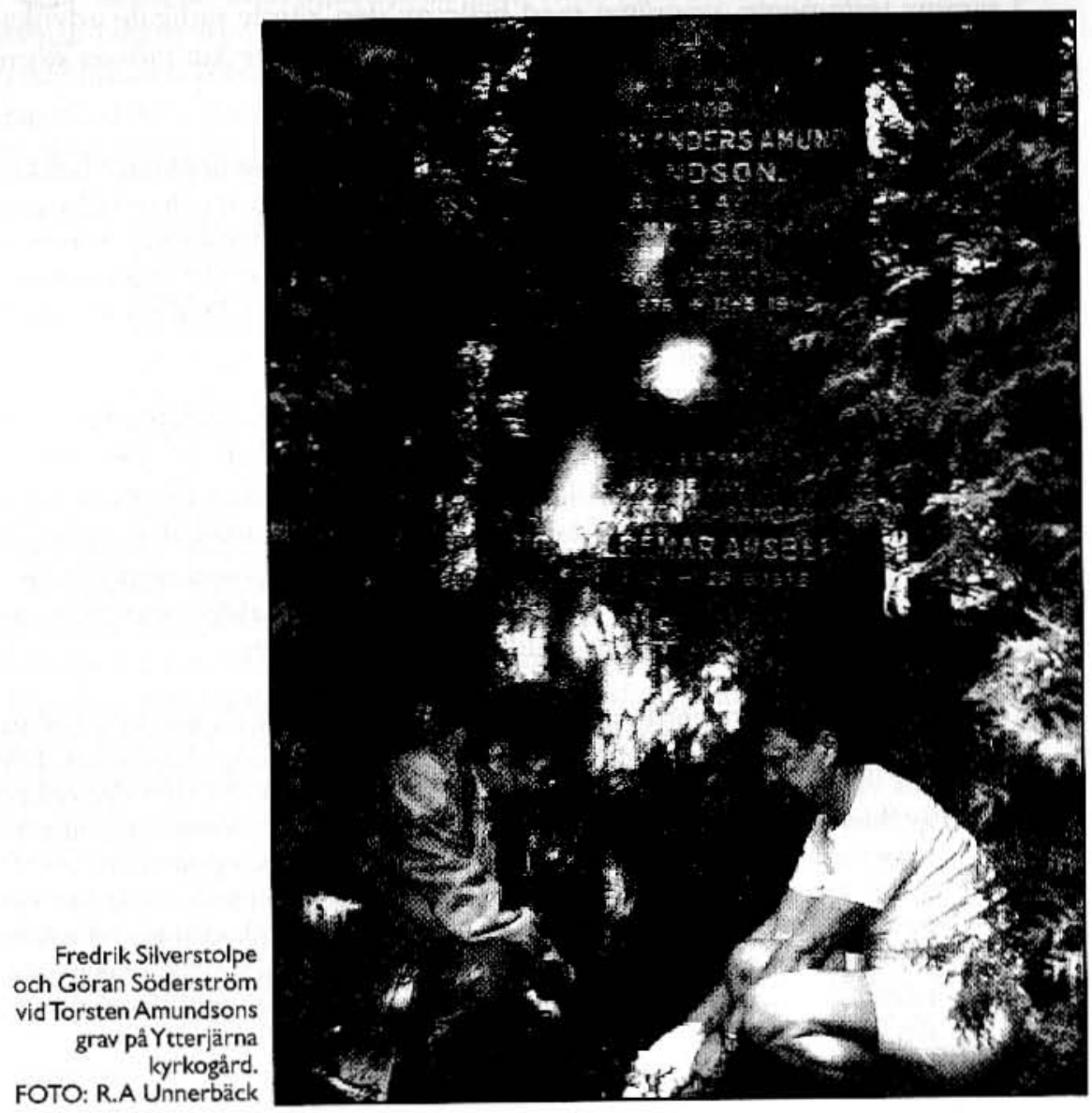

\section{Staten och "sodomiten" -}

\section{tystnaden kring homosexuella handlingar i 1600- och 1700-talets Sverige}

Jonas Liliequist

T nder senmedeltiden och början av nya tiden framträdde en ny gestal Europa - sodomiten Sodomiten var nästan altid en man som ankla gades för att ha haft sex med en annan man eller med en pojke. Men begreppet sodomi innefattade $\mathrm{i}$ bredare mening alla sexuella handlingar mellan personer av samma kön liksom samlag mellan man och kvinna på sätt som stred mot sexualitetens postulerade fortplantningssyfte liksom sexuellt umgänge med djur. ${ }^{1}$ Följande undersökning har avgränsats till den förstnämnda betydelsen. Med sodomi och homosexuella handlingar avses, om inte annat anges, sex mellan personer av manligt kön.

Med början i italienska städer inleddes under renässansen med växlande stränghet omfattande rättsliga kampanjer mot sodomiter både i nuvarande Italien och Spanien. Processerna kulminerade pă 1400- och 1500-talet i södra Europa. ${ }^{2}$ Vid 1700-talets början págick intensiva kampanjer också längre norrut, i Holland och England. Rättsprocesserna i Holland antog närmast epidemiska former och saknar motstycke i norra Europa. Under tre år från 1730-32 lagsöktes ca 300 och avrättades omkring sjuttio män och ynglingar för homosexuella handlingar. ${ }^{3}$

I det medeltida Sverige var homosexuella handlingar endast straffbelagda i kyrklig rätt. ${ }^{`}$ Äldre Västgötalagen stadgade böter för den som beskyllde en man för att ha låtit en annan man "driva otukt" med sig, men det var först $i$ 1608 års appendix till landslagen som homosexuella handlingar i sig kom att straffbeläggas enligt värdslig rätt. ${ }^{5}$ Grunden för de värdsliga straffanspråken utgjordes av ordalydelsen i Tredje Moseboken, kapitel 20, vers 13: "Du skalt icke liggia när drängar sảsom när enno qvinno. ty det är een styggelse: och the skola båda dödhen dö, theras blodh ware öfwer them." Trots den uttryckta kriminaliseringen är endast ett tiugotal rättsfall kända från 1600- och 1700-talen och i den nya lagen 1734 saknas föreskrifter helt. Detta framstär som så mycket märkligare mot bakgrund av den intensiva uppmärksamhet som rådde kring tidelagsbrottet i 1600- och 1700-talets Sverige, en uppmärksamhet som i sin tur tycks ha saknat motsvarighet på kontinenten

Hur ska man förklara de fảtaliga rättsfallen och det till synes bristande rättsliga intresset för sodomi i Sverige? 